\title{
A prospective randomised controlled study of the use of ranitidine in patients with gastric cancer
} J N Primrose, G V Miller, S R Preston, J Gokhale, N S Ambrose, U M Ward, J G Mills,
R S B Ehsanullah, B Darekar, and the Yorkshire GI Tumour Group Hospital, Leeds, UK J N Primrose

G V Miller

S R Preston

J Gokhale

U M Ward

GlaxoWellcome

Research and

Development,

Greenford, Middlesex,

UK

J G Mills

R S B Ehsanullah

B Darekar

Correspondence to: University Surgical Unit, F level, Centre Block,

Southampton General

Hospital, Tremona Rd,

Southampton, UK.

Accepted for publication 2 May 1997
St James's University

N S Ambrose Professor J N Primrose,

\begin{abstract}
Background-Does the use of the histamine $\mathrm{H}_{2}$ receptor antagonist ranitidine improve the outcome of patients with gastric cancer?
\end{abstract}

Patients-A total of 222 patients with gastric cancer who had received radical or palliative resection or who were deemed inoperable at presentation.

Setting-Hospitals within Yorkshire, the participating clinicians being members of the Yorkshire GI Tumour Group.

Methods-A multicentre prospective randomised double blind trial comparing ranitidine $150 \mathrm{mg}$ twice daily with placebo twice daily was undertaken. The principal outcome measures were survival and survival excluding those who died within 30 days of operation.

Results-The median survival (95\% confidence intervals) was 331 (232 to 393) days for patients in the ranitidine group compared with 187 (143 to 269) for those in the placebo group. The difference in survival was not statistically significant $(p=0.225)$. When patients who died within 30 days of operation were excluded ( 21 in the placebo group, 15 in the ranitidine group), the difference in survival remained not significant $(p=0.358)$. No subgroup could be identified who significantly benefited from treatment, but for patients with stage VIa cancer the median survival was 134 days with placebo compared with 313 days with ranitidine $(p=0.073)$.

Conclusion-This study does not show significant benefit from the use of ranitidine for gastric cancer but further larger studies may be indicated.

(Gut 1998;42:17-19)

Keywords: rantitidine; cimetidine; $\mathrm{H}_{2}$ histamine receptor antagonist; gastric cancer

Table 1 Demographic details and tumour staging of the patients in the study

\begin{tabular}{llll}
\hline & Placebo & Ranitidine & Total \\
\hline Number of patients & 110 & 112 & 222 \\
Number of men (\%) & $76(69)$ & $80(71)$ & $156(70)$ \\
Mean (range) age (years) & $69.6(38-88)$ & $68.1(46-89)$ & $68.8(38-89)$ \\
Mean (range) weight (kg) & $64.7(44.5-101.5)$ & $67.3(31.8-105.0)$ & $66.0(31.8-105.0)$ \\
30 day mortality (\%) & $21(19)$ & $15(13)$ & $36(16)$ \\
Tumour stage* (\%) & $5(5)$ & $7(7)$ & $12(6)$ \\
I & $17(16)$ & $23(22)$ & $40(19)$ \\
II & $46(42)$ & $41(38)$ & $87(40)$ \\
III & $17(16)$ & $17(16)$ & $34(16)$ \\
IVa & $24(22)$ & $19(18)$ & $43(20)$ \\
IVb & & \\
\hline
\end{tabular}

${ }^{\star}$ In six cases (one placebo, five ranitidine) the staging was incomplete.
Gastric cancer is a major cause of cancer death in the world accounting for 10000 deaths per year in England and Wales alone. ${ }^{1}$ There is no curative treatment other than surgery, and the overall outlook for a patient diagnosed as having the condition is dismal, in some UK series only $5 \%$ of such cases surviving five years. ${ }^{2}$ For this reason there was much interest in the report of Tonnesen et al in 1988 which showed a survival benefit in treating all such patients with cimetidine, an $\mathrm{H}_{2}$ histamine receptor antagonist. ${ }^{3}$ Several studies have subsequently been initiated to investigate this finding further. Here we report the results of a study using the more potent $\mathrm{H}_{2}$ receptor antagonist, ranitidine.

\section{Patients and methods}

Between August 1989 and March 1995, 222 patients with histologically proven gastric cancer were recruited from practices of members of the Yorkshire GI Tumour Group. Nineteen consultants from seven centres contributed patients, the numbers from each centre varying from 103 to 6 (median 19). All of the consultants had a declared interest in gastrointestinal cancer, and patients with potentially curable disease were treated radically, most surgeons preferring a $\mathrm{D}_{2}$ approach. Table 1 gives the demographic details of the patients and tumour staging. The clinicopathological staging is based on the tumour, node, metastases (TNM) system. ${ }^{2}$ To ensure consistency with the pathological reporting, all pathologists at each of the centres recruiting patients were visited to ensure that all the specimens would be examined with this staging system in view, and all agreed to participate. Most patients recruited to the study had advanced disease, with $76 \%$ being in stages III or IV. All patients in stages I-III had received a radical resection (all macroscopic tumour removed, histologically clear proximal and distal resection margins), those in stage IVa, a palliative resection, and those in stage IVb, no resection (no operation, laparotomy alone or palliative diversion).

Written informed consent was obtained as soon as possible after operation/decision not to operate. Patients were randomised to receive ranitidine $150 \mathrm{mg}$ twice daily or matching placebo twice daily when intake by mouth was permitted for up to five years. No other $\mathrm{H}_{2}$ receptor antagonists or proton pump inhibitors were permitted over the perioperative period or during the study, and the patients received no other adjuvant treatment. The patients were followed up at three monthly intervals at home by research nurses who provided medication until the completion of the study (31 March 
1995) or until death. Patients alive at the completion of the study were censored at the time of the last follow up visit.

Survival analysis was carried out using the Kaplan-Meier method and the log rank test. The effect of risk factors was investigated using Cox's proportional hazard model. All analyses used Statistical Analysis System 6.08. Analysis was on an intention to treat basis.

The study was approved by each of the clinical research (ethics) committees for the districts in which clinicians participated in the study.

\section{Results}

Of the 222 patients recruited, 110 were allocated to receive placebo and 112 ranitidine. The median length of follow up was 185 (range 1-1990) days. Follow up was complete while patients remained in the study. The groups were well matched for age, sex, and body weight (table 1). The proportion of patients with advanced disease (stages III and IV) was $76 \%$ in the placebo group and $72 \%$ in the ranitidine group. At the end of the study $71 \%$ of the patients allocated to receive placebo had died compared with $67 \%$ in the ranitidine group. All of the deaths were from gastric cancer except in 17 patients. Death in these cases was from a variety of causes, the most common of which were myocardial infarction (four) and cause unknown (four). The median (95\% confidence intervals) survival of patients receiving placebo was 187 (143 to 269) days compared with 331 (232 to 393 ) days in the ranitidine group (fig

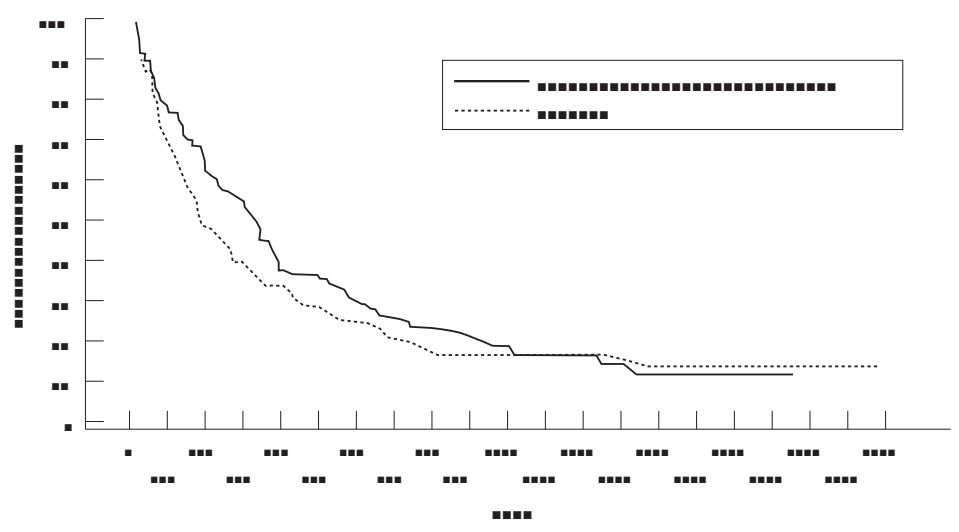

Figure 1 Overall survival by life table analysis of the patients in the study.

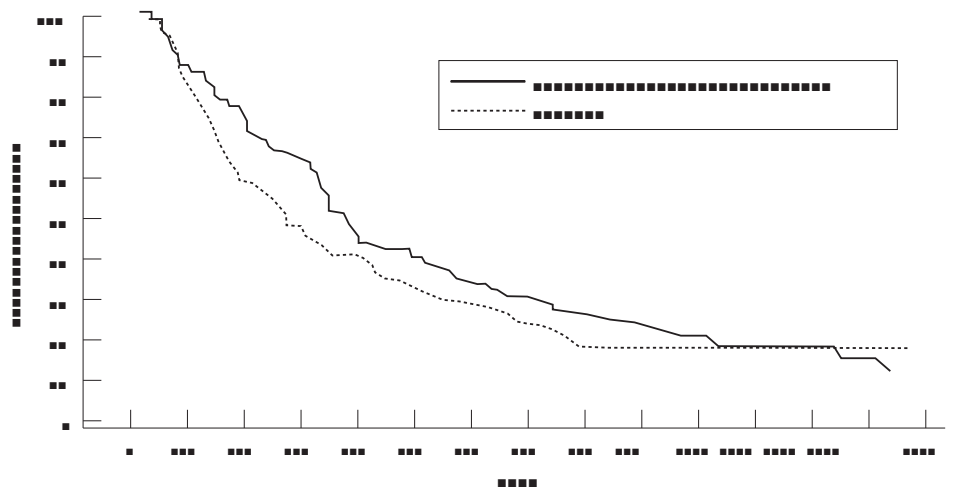

Figure 2 Overall survival by life table analysis of the patients in the study who survived 30 days after operation.
Table 2 The median survival times with regard to staging

\begin{tabular}{|c|c|c|c|c|}
\hline & $\begin{array}{l}\text { Number of } \\
\text { patients }\end{array}$ & $\begin{array}{l}\text { Number } \\
\text { died (\%) }\end{array}$ & $\begin{array}{l}\text { Median } \\
\text { survival } \\
\text { (days) }\end{array}$ & $\begin{array}{l}p \text { Value } \\
\text { (log rank } \\
\text { test) }\end{array}$ \\
\hline \multicolumn{5}{|l|}{ Stage I } \\
\hline Ranitidine & 7 & 0 & - & \multirow[t]{2}{*}{-} \\
\hline Placebo & 5 & $1(20)$ & - & \\
\hline \multicolumn{5}{|l|}{ Stage II } \\
\hline Ranitidine & 23 & $13(57)$ & 744 & \multirow{2}{*}{0.685} \\
\hline Placebo & 17 & $7(41)$ & 612 & \\
\hline \multicolumn{5}{|l|}{ Stage III } \\
\hline Ranitidine & 41 & $26(63)$ & 377 & \multirow{2}{*}{0.282} \\
\hline Placebo & 46 & $31(67)$ & 266 & \\
\hline \multicolumn{5}{|l|}{ Stage IVa } \\
\hline Ranitidine & 17 & $16(94)$ & 313 & \multirow{2}{*}{0.073} \\
\hline Placebo & 17 & $15(88)$ & 134 & \\
\hline \multicolumn{5}{|l|}{ Stage IVb } \\
\hline Ranitidine & 19 & $18(95)$ & 75 & \multirow{2}{*}{0.882} \\
\hline Placebo & 24 & $23(96)$ & 62 & \\
\hline
\end{tabular}

1). The difference in survival did not achieve statistical significance $(\mathrm{p}=0.225)$. Excluding patients who died within 30 days of operation (21 in the placebo group, 15 in the ranitidine group), the median survival was 266 (187 to 247) days in the placebo group and 377 (321 to $568)$ days in the ranitidine group $(p=0.358)$ (fig 2). Exclusion of patients who died after the perioperative period of causes other than gastric cancer also had no effect on the results.

Using Cox's proportional hazard model, four "risk factors" were examined: treatment, age, sex, and tumour stage. Of these, only tumour stage had a significant effect on survival, the more advanced the tumour the shorter the survival time $(p<0.001)$. No significant difference between treatment groups could be identified when analysed by stage (table 2), although in stage IVa (palliative excision) the $\mathrm{p}$ value approaches significance $(\mathrm{p}=0.073)$.

\section{Discussion}

This study does not show a statistically significant survival benefit from the use of ranitidine in patients with gastric cancer. The results, however, are tantalising. In the previous study by Tonnesen $e t a l^{3}$ the one year survival in the cimetidine group was $45 \%$ compared with $28 \%$ on placebo. This compares with $43 \%$ ranitidine $/ 33 \%$ placebo in the present study. The corresponding two year survival figures are $22 \%$ cimetidine $13 \%$ placebo and $25 \%$ ranitidine $/ 19 \%$ placebo. The median survival after five years in the Tonnesen study was 450 days in the cimetidine group and 316 days with placebo $(\mathrm{p}=0.02)$ and this compares with median survivals of 331 days in the ranitidine group and 187 days in the placebo group. Thus the direction of the treatment effect is the same but the magnitude of that effect is less in this study. Interestingly, the trend towards benefit is of the same order as that shown in a recently reported double blind placebo controlled study of cimetidine in colonic cancer. ${ }^{4}$

There are several differences between the present study and that reported by Tonnesen $e t$ $a l .^{3}$ Firstly, we only sought to examine the effect of treatment given after either intake by mouth resumed after surgical resection or the decision was made not to operate. In the previous study, treatment was commenced intravenously in some cases before being continued by mouth. 
It is possible, although unlikely, that an effect, perhaps immunological, over a very early critical postoperative period might have influenced outcome. Secondly, ranitidine and not cimetidine was used in this study.

Several mechanisms may explain any potential benefit of $\mathrm{H}_{2}$ receptor antagonists in patients with gastric cancer. One of these concerns the effect of these drugs on the immune system. Cimetidine and ranitidine have long been known to have effects on the immune system, including the inhibition of T-suppressor activity and the enhancement of interleukin-2 production from lymphocytes. ${ }^{56}$ It has also been suggested that these immunological effects may not involve a classical $\mathrm{H}_{2}$ receptor mediated pathway and that cimetidine may be a more potent immunomodulator than ranitidine or famotidine which are more potent antagonists at the $\mathrm{H}_{2}$ receptor, ${ }^{7}$ at least in patients with gastric cancer. This may be relevant to the present study. However, another way in which $\mathrm{H}_{2}$ receptor antagonists may influence outcome is via a direct interaction with $\mathrm{H}_{2}$ receptors on cancer cells. Gastric cancer cell lines may express $\mathrm{H}_{2}$ receptors ${ }^{8}$ and, although studies on human cancers have not yet been reported, $\mathrm{H}_{2}$ receptor antagonists appear to have antitumour activity in xenograft studies performed with human gastric cancer cells. $^{9}$

Although the results of this study are negative with respect to a beneficial effect of ranitidine in gastric cancer, they support the need for further appropriately sized trials in this area. This study comprised over 200 patients but to show significant benefit a study of 2000 patients would be required, assuming a consistent improvement in the two year survival from 20 to $25 \%$ (two sided significance $\mathrm{p}<0.05$, power $80 \%$ ). The importance of such an improvement in survival should not be underestimated. $\mathrm{H}_{2}$ receptor antagonists are extremely safe compounds with excellent side effect profiles. ${ }^{10} \mathrm{~A}$ very small beneficial effect on survival in patients with gastric cancer assumes quite considerable importance since quality of life is unlikely to be diminished by taking $\mathrm{H}_{2}$ receptor antagonists and the disease is common. In this respect the analogy with endocrine treatment of breast cancer is relevant. ${ }^{11}$
We await with interest the results of the British Stomach Cancer Group study on the use of cimetidine for stomach cancer and also the results of a similar study using ranitidine in the West of Scotland (C McArdle, personal communication, 1992). It may then be apparent whether further studies are indicated.

The authors wish to thank Jill Kellett, Research Nurse, who undertook much of the follow up of patients in this study. G V M, S R P and J G were supported by a grant from GlaxoWellcome.

The Yorkshire GI Tumour Group consists of: Professor P J Guillou (Chairman), Mr M I Aldoori, Mr J Alexander, Mr C L O Allen, Mr N S Ambrose, Dr D V Ash, Mr R J Ausobsky, Dr C Bennett, Mr S G Brooks, Mr A C Broughton, Dr S M Crawford, Dr A M Crellin, Mr P Dewar, Dr M F Dixon, Dr D Dodwell, Mr L A Donaldson, Mr G Duthie, Mr P J Finan, Dr J Gokhale, Mr R J R Goodhall, Mr N R Hall, Dr K M Harris, Mr Gokhale, Mr R J R Goodhall, Mr N R Hall, Dr K M Harris, Mr
J Harrison, Mr P Holdsworth, Mr I F Hutchinson, Mr C J H J Harrison, Mr P Holdsworth, Mr I F Hutchinson, Mr C J H
Ingoldby, Dr J K Joffe, Professor D Johnston, Dr S Kaftan, Mr C R Kapadia, Mr P W R Lee, Mr D J Leinhardt, Mr S H Leveson, Mr J P A Lodge, Mr V S D Logan, Mr P J Lyndon, Mr R C Macdonald, Mr J Macfie, Dr J May, Mr A W F McAdam, $\mathrm{Mr}$ M J McMahon, Mr P Murchan, Mr A J Mearns, Professor J R T Monson, Mr A H Nejin, Dr T J Perren, Dr P Quirke, Mr C Rawlings, Mr J V Reynolds, Mr P Sagar, Mr P Sahay, Dr D Sebag-Montefiore, Professor P J Selby, Dr M T Seymour, Dr A V Simmons, Mr S Somers, Mr H M Sue-Ling, Dr R E Taylor, V Simmons, Mr S Somers, Mr H M Sue-Ling, Dr R E Taylor,
Dr G Turner, Mr C M White, Mr A Windsor, Mr N Womack, Dr G Turner, Mr C M White,
Dr J I Wyatt, Mr C K Yeung.

1 Cancer Research Council. Factsheet 18. London: Cancer Research Campaign, 1993.

2 Fielding JWL, Roginski C, Ellis DJ, et al. Clinicopathological staging of gastric cancer. Br F Surg 1984;71:667-80.

3 Tonnesen H, Bulow S, Fischerman K, et al. The effect of cimetidine on survival after gastric cancer. Lancet 1988;ii: $990-2$.

4 Svendsen LB, Ross C, Knigge U, et al. Cimetidine as an adjuvant treatment in colorectal cancer. A double-blind, randomized pilot study. Dis Colon Rectum 1995;38:514-18.

5 Gifford RRM, Tilberg AF. Histamine type 2 receptor antagonist immune modulation. II. Cimetidine and ranitidine increase interleukin 2 production. Surgery 1987;102: 242-7.

6 Griswold DE, Alessi S, Badger AM, et al. Inhibition of T suppressor cell expression by histamine type 2 receptor antagonists. F Immunol 1984;132:3054-7.

$7 \mathrm{Hahm} \mathrm{KB}$, Lee SI, Chung JP, et al. Comparison of immunomodulative effects of histamine- 2 receptor antagonists in gastric cancer patients: focus on the lymphoblastnists in gastric cancer patients: focus on the lymphoblast-
ogenesis and cytotoxicity of peripheral blood mononuclear ogenesis and cytotoxicity of peripheral blood $\mathrm{m}$.
cells. Int f Immunopharmacol 1994;16:985-93.

8 Laboisse CL, Augeron C, Couturier-Turpin M-H, et al. Characterization of a newly established human gastric cancer cell line HOT-1 bearing histamine $\mathrm{H}_{2}$ receptors. Cancer Res 1982;42:1542.

9 Watson SA, Wilkinson LJ, Robertson JF, Hardcastle JD. Effect of histamine on the growth of human gastrointestinal tumours: reversal by cimetidine. Gut 1993;34:1091-6.

10 Colin-Jones DG, Langman MJ, Lawson DH, et al. Postmarketing surveillance of the safety of cimetidine: 10 year mortality report. Gut 1992;33:1280-4.

11 Early Breast Cancer Trialists' Collaborative Group. Systemic treatment of early breast cancer by hormonal, cytotoxic, or immune therapy. Lancet 1992;339:1-15, $71-85$. 